\title{
Dietary exposure to melamine and cyanuric acid induced growth reduction, oxidative stress and pathological changes of hepatopancreas in Pacific white shrimp
}

\author{
Nutt Nuntapong • Wutiporn Phromkunthong (D) Sunee Wanlem • \\ Mali Boonyaratpalin
}

Received: 14 August 2018/Accepted: 7 February 2019/Published online: 15 February 2019

(C) The Author(s) 2019

\begin{abstract}
This study examined the effects of dietary melamine (MEL) and cyanuric acid (CYA) singly and in combination on growth, nutrient utilization, immunological responses, oxidative stress, and histological changes in Pacific white shrimp. Seven experimental isonitrogenous (35\%) and isolipidic (8\%) diets were formulated, namely diet 1 (a control diet without MEL and CYA); diets 2-5 (with MEL and CYA at $2.5+2.5,5+5,7.5+7.5$ and $10+10 \mathrm{~g} \mathrm{~kg}^{-1}$ diet); diet 6 (with only MEL at $10 \mathrm{~g} \mathrm{~kg}^{-1}$ diet) and diet 7 (with CYA alone at $10 \mathrm{~g} \mathrm{~kg}^{-1}$ diet). The shrimp with initial body weight $2.37 \pm 0.02 \mathrm{~g}$ were fed with these diets for 10 weeks. The results indicate that all the diets with MEL and CYA singly or in combination had adverse effects on growth and nutrient utilization relative to the control diet $(p<0.05)$. Total protease and trypsin activities were significantly lowered by all diets containing MEL $(p<0.05)$. Haemolymph parameters, including total hemocyte count, phenoloxidase (PO) activity, respiratory burst, and lysozyme activity, were significantly decreased $(p<0.05)$ in shrimp receiving MEL alone $\left(10 \mathrm{~g} \mathrm{~kg}^{-1}\right.$ diet $)$ and at high combination dosages $\left(10+10 \mathrm{~g} \mathrm{~kg}^{-1}\right.$ diet $)$. Moreover, MEL and CYA induced oxidative stress, damaged hepatopancreas, decreased antioxidant responses, increased lipid peroxidation, and caused abnormality of hepatocytes.
\end{abstract}

Keywords Pacific white shrimp $\cdot$ Melamine $\cdot$ Cyanuric acid $\cdot$ Growth $\cdot$ Histology $\cdot$ Oxidative stress

\section{Introduction}

Feed contamination is a worldwide major current concern with regard to consumer health, economic losses, and safety and reliability of food products (Maule et al. 2007; Pettersson 2012; O'Keefe and Campabadal 2015). In general, melamine (MEL) and its derivatives including cyanuric acid (CYA), ammeline (AMN), and ammelide (AMD), are commonly used in thermoplastic materials, such as dishware, laminating resins, coating materials, and fire retardants (Casu et al. 1997; Roviello et al. 2015). Moreover, the US Food and Drug Administration (2007) reported illegal adulteration of animal feed with MEL and CYA in many countries.

N. Nuntapong · W. Phromkunthong $(\bowtie)$

Kidchakan Supamattaya Aquatic Animal Health Research Center, Department of Aquatic Science, Faculty of Natural

Resources, Prince of Songkla University, Songkhla 90112, Thailand

e-mail: wutipornp@yahoo.com

S. Wanlem

Faculty of Veterinary Science, Prince of Songkla University, Songkhla 90112, Thailand

M. Boonyaratpalin

Department of Fisheries, Ministry of Agriculture and Cooperative Affair, Bangkok 10900, Thailand 
MEL is a nitrogenous material with $66 \%$ nitrogen by mass. Therefore, adding MEL in a foodstuff increases the total nitrogen content typically determined by the Kjeldahl method to estimate the protein content, so MEL is also known as a "fake protein" (US-FDA 2007; Reimschuessel et al. 2008). For this reason, protein-rich ingredients are the major targets for MEL adulteration that has been documented in many feedstuffs, such as fishmeal, gluten, soybean meal, squid meal, and shrimp meal, and contamination of pets and farm animals including fish and shrimp has also been reported (Ehling et al. 2007; WHO 2009). Adverse effects of MEL and CYA have been reported in different fish species; these included growth retardation, behavioral abnormalities, immunosuppression, hepatotoxicity and nephrotoxicity (Reimschuessel et al. 2010; Xue et al. 2011; Pirarat et al. 2012; Pacini et al. 2013; Phromkunthong et al. 2013, 2015a, b; Mahardika et al. 2017). Thus, contamination of feed with MEL and CYA is one of the critical concerns in aquatic industry. To date, due to its toxic effects and other potential health effects impacting consumers, many countries have incorporated MEL and its structural analogs into a list of food additives and substances prohibited in animal feeds. In Europe, the maximum permitted levels of MEL in feed are strictly set as $2.5 \mathrm{mg} \mathrm{kg}^{-1}$ (European Commission 2013). In 2016, the Department of Livestock Development, Thailand has banned dried squid-derived meal imported from Vietnam after laboratory tests indicated the presence of CYA (Byrne 2016), and there is evidence that these chemical substances are still being used illegally in some parts of the world.

The culturing of Pacific white shrimp (Litopenaeus vannamei) is gaining importance in the food sector, with the increasing trend worldwide since 2004 (World Bank 2013). This species has great global demand due to good taste and high nutritional value (FAO 2016). For producing high-quality shrimp, the feed used in culturing is a key factor. In recent years, shrimp feed development has focused on the suitability of protein sources and the reduction of production costs without negative effects on growth and health status of the shrimp (Amaya et al. 2007; Carvalho et al. 2016). Shrimp feed needs to have a high protein content to stimulate growth and feed utilization, so it is a suitable target for adulteration by MEL and its derivatives (Karbiwnyk et al. 2010). In fact, there are a few reports of adulteration of shrimp feed by MEL and its derivatives. Lightner et al. (2009) reported diagnostic results on black tiger shrimp, Penaeus monodon, and Pacific white shrimp from India and Indonesia. Golden to greenish-brown needle-like crystals were present in the antennal glands, a likely adverse effect from MEL and CYA poisoning. In contrast, JAVMA (2007) reported that MEL has been intentionally added into shrimp feeds in the USA, to improve water stability. However, after an incident was caused by use of MEL in 2007, its use as a pellet binder was discontinued.

A few recent reports have mentioned the toxicity of MEL and CYA to crustaceans, especially the penaeid shrimp (Lightner et al. 2009; Karbiwnyk et al. 2010). Hence, this present study investigated the effects of MEL and CYA supplementation, singly or in combination, in practical feed for Pacific white shrimp. The effects on growth, nutrient utilization, oxidative stress, immunological responses and histopathological changes were evaluated. This study improves the understanding of shrimp responses to MEL and CYA exposures.

\section{Materials and methods}

Experimental conditions and setup

This study was conducted at Kidchakan Supamattaya Aquatic Animal Health Research Center (KS-AAHRC), Department of Aquatic Science, Faculty of Natural Resources, Prince of Songkla University, Hat Yai, Thailand. Sea water with $30 \%$ salinity was transported from a commercial shrimp farm located in Songkhla Province, Thailand, stocked in a $7 \mathrm{~m}^{3}$ concrete pond with continuous aeration, and was diluted with dechlorinated freshwater to $15 \%$ o brackish water that was used for the entire experiment. The water quality parameters monitored for suitability to a marine shrimp culture included DO, alkalinity, and $\mathrm{pH}$ (Thai Agricultural Standards TAS 7401-2009 2009). The salinity was determined using a handheld refractometer (ATAGO, Tokyo, Japan), while alkalinity was controlled to a sodium bicarbonate titration level $\left(120 \mathrm{mg} \mathrm{L}^{-1}\right)$ and $\mathrm{pH}$ 7.8-8.2. The feeding trial was conducted in $200 \mathrm{~L}$ fiberglass tanks. Each tank was equipped with an air stone and water draining system, and was covered with a plastic tray to prevent escape of the shrimp. 
Test shrimp and feeding

A completely random design (CRD) was used in this study. Pacific white shrimp, L. vannamei $(0.5-1.0 \mathrm{~g}$ average weight) were acclimated in a $3 \mathrm{~m}^{3}$ indoor concrete pond with $15 \%$ brackish water and fed with the control feed (diet 1 without MEL or CYA) four times daily for 3 weeks. At the initiation of feeding experiment, 18 shrimp with an average body weight of $2.37 \pm 0.02 \mathrm{~g}$ were randomly released into 35 fiberglass tanks $(200 \mathrm{~L})$. Each tank was then randomly assigned to one of five replicates of the seven dietary treatments. The shrimp were fed to apparent satiation four times daily, for 10 weeks. The care and handling of the white shrimp were in accordance with the guidelines of the Canadian Council on Animal Care (CCAC 2005) and with Thai Agricultural Standards TAS 7401-2009 (2009).

Diet preparation

Seven isonitrogenous (35\% crude protein) and isolipidic (8\% crude lipid) laboratory-made diets were formulated to meet the nutritional requirements of Pacific white shrimp. Major protein ingredients used in the diets were provided from Charoen Pokphand Foods PCL, Songkhla, Thailand. MEL with $99.5 \%$ purity was supplied by Chang Chun Petrochemical Co. Ltd., Taiwan. CYA (98\% purity) was purchased from SigmaAldrich (MO, USA). The experimental diets are detailed in Table 1. Diet 1 had no added MEL or CYA; MEL and CYA were incorporated $\left(\mathrm{g} \mathrm{kg}^{-1}\right.$ diet) at levels $2.5+2.5$ (diet 2), $5+5$ (diet 3), $7.5+7.5$ (diet 4), $10+10(\operatorname{diet} 5), 10+0(\operatorname{diet} 6)$, and $0+10(\operatorname{diet} 7)$, respectively. The diets were processed at the KSAAHRC using Hobart mixer A-200 (OH, USA). All the dry raw ingredients were finely ground, passed

Table 1 Ingredients and formulations of the experimental diets

\begin{tabular}{|c|c|c|c|c|c|c|c|}
\hline \multirow{2}{*}{$\begin{array}{l}\text { Ingredient } \\
\left(\mathrm{g} \mathrm{kg}^{-1} \text { diet }\right)\end{array}$} & \multicolumn{7}{|c|}{ Diet $\left(\mathrm{MEL}+\mathrm{CYA}, \mathrm{g} \mathrm{kg}^{-1}\right.$ diet $)$} \\
\hline & $\begin{array}{l}\text { Diet } 1 \\
\text { (Control) }\end{array}$ & $\begin{array}{l}\text { Diet } 2(2.5+ \\
2.5)\end{array}$ & $\begin{array}{l}\text { Diet } 3(5+ \\
5)\end{array}$ & $\begin{array}{l}\text { Diet } 4(7.5+ \\
7.5)\end{array}$ & $\begin{array}{l}\text { Diet } 5(10+ \\
10)\end{array}$ & $\begin{array}{l}\text { Diet } 6(10 \\
+0)\end{array}$ & $\begin{array}{l}\text { Diet } 7(0+ \\
10)\end{array}$ \\
\hline Fish meal & 200 & 200 & 200 & 200 & 200 & 200 & 200 \\
\hline $\begin{array}{l}\text { De-hulled soybean } \\
\text { meal }\end{array}$ & 250 & 250 & 250 & 250 & 250 & 250 & 250 \\
\hline Squid liver meal & 30 & 30 & 30 & 30 & 30 & 30 & 30 \\
\hline Corn gluten & 50 & 50 & 50 & 50 & 50 & 50 & 50 \\
\hline Canola meal & 28.5 & 28.5 & 28.5 & 28.5 & 28.5 & 28.5 & 28.5 \\
\hline Wheat flour & 320 & 320 & 320 & 320 & 320 & 320 & 320 \\
\hline Wheat gluten & 30 & 30 & 30 & 30 & 30 & 30 & 30 \\
\hline Fish oil & 15 & 15 & 15 & 15 & 15 & 15 & 15 \\
\hline Soybean oil & 1 & 1 & 1 & 1 & 1 & 1 & 1 \\
\hline Lecithin & 20 & 20 & 20 & 20 & 20 & 20 & 20 \\
\hline $\begin{array}{l}\text { Vitamin and mineral } \\
\text { premix }^{\mathrm{a}}\end{array}$ & 2 & 2 & 2 & 2 & 2 & 2 & 2 \\
\hline Di-calcium phosphate & 22 & 22 & 22 & 22 & 22 & 22 & 22 \\
\hline Choline chloride & 1 & 1 & 1 & 1 & 1 & 1 & 1 \\
\hline Inosital & 0.5 & 0.5 & 0.5 & 0.5 & 0.5 & 0.5 & 0.5 \\
\hline Melamine $(\mathrm{MEL})^{\mathrm{b}}$ & 0 & 2.5 & 5 & 7.5 & 10 & 10 & 0 \\
\hline Cyanuric acid $(\mathrm{CYA})^{\mathrm{c}}$ & 0 & 2.5 & 5 & 7.5 & 10 & 0 & 10 \\
\hline $\begin{array}{l}\text { Microcrystalline } \\
\text { cellulose }\end{array}$ & 30 & 25 & 20 & 15 & 10 & 20 & 20 \\
\hline
\end{tabular}

${ }^{\mathrm{a}}$ Vitamin and mineral premixed (unit $\mathrm{kg}^{-1}$ feed): retinal (A) $7000 \mathrm{IU}$; cholecalciferol (D3) $3000 \mathrm{IU}$; tocopherol (E) $1500 \mathrm{mg}$; menadione sodium bisulfite (K3) $30 \mathrm{mg}$; thiamine (B1) $25 \mathrm{mg}$; riboflavin (B2) $20 \mathrm{mg}$; pyridoxine (B6) $25 \mathrm{mg}$; cobalamin (B12) $0.02 \mathrm{mg}$; niacin $100 \mathrm{mg}$; pantotenic acid $80 \mathrm{mg}$; ascorbic acid (C) $200 \mathrm{mg}$; biotin $1 \mathrm{mg}$; folic acid $10 \mathrm{mg}$; $\mathrm{Cu} 25 \mathrm{mg}$; Fe $30 \mathrm{mg}$; Mn $30 \mathrm{mg}$; I $1 \mathrm{mg}$; Co $0.2 \mathrm{mg}$; Zn $100 \mathrm{mg}$; Se $0.35 \mathrm{mg}$

${ }^{b}$ Melamine: Chang Chun Petrochemical Co., Ltd., Taipei Taiwan (purity 99.5\%)

${ }^{\mathrm{c} C y a n u r i c}$ acid (98\%): Sigma, Aldrich Co., Ltd. 
through a 30-mesh sieve, and weighed. After mixing for $15 \mathrm{~min}$, lipid sources (fish oil, soybean oil, and lecithin) and distilled water $\left(400 \mathrm{~mL} \mathrm{~kg}^{-1}\right.$ feed) were added with continuous mixing. The homogenous mixture was pelleted (3-mm diameter) and dried to below $10 \%$ moisture. The dry pellets were then packed in low-density polyethylene bags and stored in a freezer at $-20{ }^{\circ} \mathrm{C}$. The experimental diets were analyzed for proximal composition according to the standard methods of AOAC (1995). The proximal compositions are presented in Table 2. MEL and CYA content in the diets were determined by LC-MS/MS using a modified method of US-FDA LIB No. 4422 with HILIC chromatography (Smoker and Krynitsky 2008), as described in our previous publication (Phromkunthong et al. 2013, 2015a).

\section{Growth performance}

In the beginning and at the end of the dietary treatment trial, the shrimp in each tank were counted and bulk weighed after immersing in low-temperature water $\left(22^{\circ} \mathrm{C}\right)$ to reduce their physical activity. The mean final weight, number of shrimp, and feed intake were determined for each tank to calculate growth parameters, feed utilization and survival according to Kim et al. (2011) as follows:

Weight gain $(\mathrm{g})=$ final body weight $(\mathrm{g})$ - initial body weight $(\mathrm{g})$.

Average daily gain $\left(\mathrm{ADG}, \mathrm{g}\right.$ shrimp ${ }^{-1}$ day $\left.^{-1}\right)=[$ final body weight $(\mathrm{g})$ - initial body weight $(\mathrm{g})] /$ days .

Specific growth rate $\left(\mathrm{SGR}, \% \mathrm{day}^{-1}\right)=[(\ln$ final body weight $(\mathrm{g})-\ln$ initial body weight $(\mathrm{g})) /$ days $] \times 100$.

Feed conversion ratio $(\mathrm{FCR})=$ dry feed intake $(\mathrm{g}) /$ weight gain $(\mathrm{g})$.

Feed intake (FI, g shrimp ${ }^{-1}$ day $\left.^{-1}\right)=[$ feed consumed $(\mathrm{g}) /$ number of shrimp $] /$ days.

Survival $(\%)=100 \times($ final count of shrimp $) /($ initial count of shrimp $)$.

Chemical composition analyzes

At the beginning of the experiment, 20 shrimp were scarified and they were stored at $-20{ }^{\circ} \mathrm{C}$ until analysis of the initial proximate composition. At the end of the feeding trial, 3 shrimp from each tank (15 shrimp per treatment group) were collected to analyze the whole body composition. Nitrogen, crude lipid, moisture and ash content in the whole body were determined following the procedures of AOAC (1995). Briefly, dry matter was determined by drying the samples in a hot air oven (Memmert UF110, Germany) at $105{ }^{\circ} \mathrm{C}$ until constant weight. Nitrogen content $(\mathrm{N} \times 6.25)$ was determined by the Kjeldahl method using Kjeltec protein analyzer (Kjeltec $^{\mathrm{TM}} 8100$, FOSS, Tecator, Sweden). Crude lipid was determined by methylene chloride extraction using Soxhlet method (Soxtec ${ }^{\mathrm{TM}} 8000$, China). Ash was measured after combustion in a muffle furnace (Gallenkamp Box Furnace, UK) at $550{ }^{\circ} \mathrm{C}$ for $6 \mathrm{~h}$.

Hemolymph analysis and immunological response

Hemolymph from individual shrimp ( $n=10 /$ test group) was collected without the use of anticoagulants in week 10, after the final weights of the shrimp in all treatment groups were recorded. Haemolymph was withdrawn from the base of the 3rd walking leg of each shrimp, using a $1 \mathrm{~mL}$ syringe with $25 \mathrm{G}$ ( 25 gage) needle, and then immediately transferred into $1.7 \mathrm{~mL}$ sterile micro-centrifuge tubes. Soluble protein concentration was determined by the method of Bradford (1976). Hemolymph parameters related to immune functions were analyzed by the methods described below.

Total hemocyte count (THC)

THC was determined by the method previously described by Supamattaya et al. (2005). Briefly, $50 \mu \mathrm{L}$ of haemolymph was diluted with $450 \mu \mathrm{L}$ pre-cooled $\left(4{ }^{\circ} \mathrm{C}\right)$ trypan blue solution $(0.5 \%$ trypan blue in $2.6 \% \mathrm{NaCl})$ and gently mixed. Hemocytes were counted using a haemocytometer (Bright-Line ${ }^{\mathrm{TM}}$, NY, USA) under a compound microscope (Olympus CH30, Tokyo, Japan) and recorded as the number of cells (total hemocytes $\left.\mathrm{mL}^{-1}\right)$. 


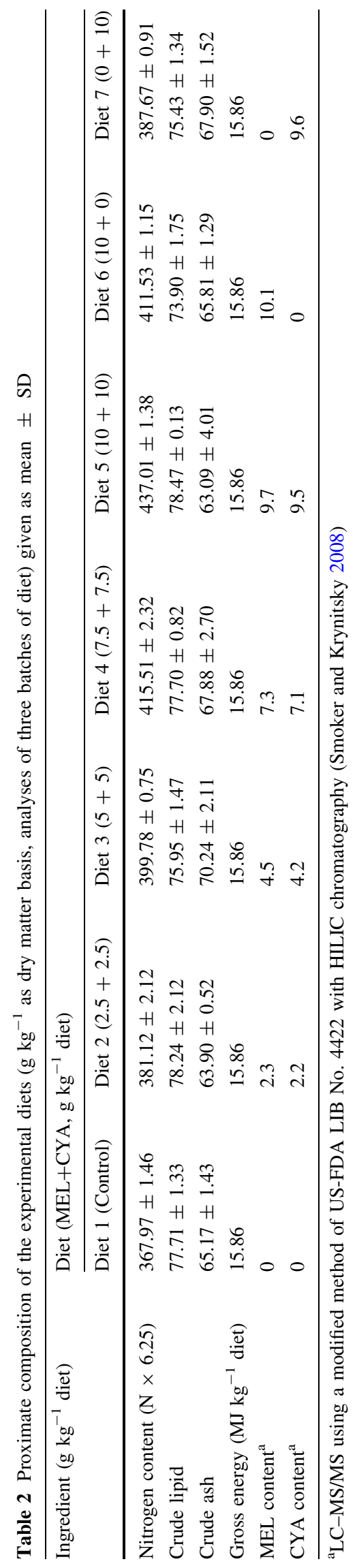


Phenoloxidase (PO) activity

PO activity was determined according to the method of Liu et al. (2004) with minor modifications. Briefly, $100 \mu \mathrm{L}$ of haemolymph was transferred into sterile micro-centrifuge tube containing $100 \mu \mathrm{L}$ cacodylate (CAC) buffer (10 mM sodium cacodylate, $0.45 \mathrm{M} \mathrm{NaCl}, 10 \mathrm{mM} \mathrm{CaCl}, 0.26 \mathrm{M} \mathrm{MgCl}_{2}$ ) at pH 7.4 and flushed with liquid nitrogen. The glaced mixture was broken down with a sterile plastic pestle, and centrifuged (Avanti $^{\mathrm{TM}_{30}}$, Beckman Coulter, CA, USA) at $12,879 \times g$ for $10 \mathrm{~min}$ at $4{ }^{\circ} \mathrm{C}$. The supernatant $(25 \mu \mathrm{L}) \mathrm{was}$ collected and placed in a well of a flat-bottomed 96-well plate. An enzyme reaction was started by adding 25 $\mu \mathrm{L}$ trypsin (Sigma-Aldrich, Buchs, Switzerland) $\left(1 \mathrm{mg} \mathrm{mL}^{-1}\right.$ in CAC buffer) and the plate was incubated at $25^{\circ} \mathrm{C}$ for $2 \mathrm{~min}$. Finally, $150 \mu \mathrm{l}$ of CAC buffer and $50 \mu \mathrm{l}$ of L-dihydroxyphenylalanine (L-DOPA, SigmaAldrich, Shanghai, China) (3 mg mL $\mathrm{mL}^{-1}$ in CAC buffer) were mixed. The optical density at $490 \mathrm{~nm}$ was recorded in kinetic mode every minute for a total of $30 \mathrm{~min}$ using a microplate spectrophotometer (PowerWave $_{\mathrm{x}}$, Bio-Tek Instruments, VT, USA). One unit of PO activity was defined as increasing the absorbance by $0.001 \mathrm{~min}^{-1}$, and the results are reported as unit $\mathrm{min}^{-1} \mathrm{mg}$ protein ${ }^{-1}$.

Respiratory burst activity

Study of respiratory burst activity of the haemocytes was performed following the method as described by Hsu and Chen (2007). Briefly, $100 \mu \mathrm{L}$ hemolymph was incubated with nitro-blue tetrazolium (NBT, SigmaAldrich, MO, USA) solution $(0.3 \%$ in $1.5 \% \mathrm{NaCl})$. The mixture was removed and the pellet was fixed with $100 \%$ methanol, and washed three times with $100 \mu \mathrm{L} 70 \%$ methanol. After air drying, formazan was dissolved by the addition of $120 \mu \mathrm{L} 2 \mathrm{M} \mathrm{KOH}$ and $140 \mu \mathrm{L}$ dimethyl sulfoxide (DMSO). The optical density at $630 \mathrm{~nm}$ was measured using a microplate reader, and is expressed as NBT reduction in $100 \mu \mathrm{L}$ haemolymph.

\section{Lysozyme}

Lysozyme activity was observed through enzyme activity and bacterial target clearance during incubation. The suspension of $0.02 \%$ lyophilized Micrococcus lysodeikticus (Sigma-Aldrich, MO, USA) in $50 \mathrm{mM}$ phosphate buffer saline at pH 6.2 was used as the substrate. Lysozyme activity was measured following the method described by Shen et al. (2010). Briefly, $25 \mu \mathrm{L}$ of diluted hemolymph was mixed with $175 \mu \mathrm{L}$ of the substrate in a flat-bottomed 96-well plate. The reaction was carried out at room temperature, and the absorbance at $490 \mathrm{~nm}$ was measured in kinetic mode every minute for a total of $10 \mathrm{~min}$, using a microplate reader. One unit of lysozyme activity was defined as reducing the absorbance by 0.001 per min (Ellis 1990), and results are reported in unit $\mathrm{mL}^{-1}$.

Antioxidant enzyme analysis and lipid peroxidation assays

Antioxidant enzyme activities of catalase (CAT), glutathione peroxidase (GPx), and superoxide dismutase (SOD) were determined at end of the feeding study. At the same time with hemolymph collection, the gill and the hepatopancreas of the same individual were dissected rapidly in an ice-cooled petri dish, and were then transferred to cryogenic vials (Corning $®$, Mexico City, Mexico) that were immediately stored in liquid nitrogen. Prior to analysis, the target tissue was individually homogenized $(1: 2,1: 4 \mathrm{w} / \mathrm{v}$ for gill and hepatopancreas tissues, respectively) in ice-cold extraction buffer ( $80 \mathrm{mM}$ potassium acetate, $4 \mathrm{mM}$ magnesium acetate, $20 \mathrm{mM}$ Hepes, $\mathrm{pH} 7.5,20 \%$ protease inhibitor, Amresco), and was then centrifuged at $12,879 \times g$ for $15 \mathrm{~min}$ at $4{ }^{\circ} \mathrm{C}$. The supernatant was transferred into a new $1.7 \mathrm{~mL}$ micro-centrifuge tube for enzyme activities assay. Protein content in enzyme extract was measured by the method of Bradford (1976) using bovine serum albumin (Sigma-Aldrich, MO, USA) as the protein standard.

CAT activity was determined based on formaldehyde production from reacting the sample with hydrogen peroxide $\left(\mathrm{H}_{2} \mathrm{O}_{2}\right)$. Formaldehyde concentration was determined from colored complexes it forms with Purpald® (4-amino-3-hydrazino-5-mercapto-1,2,4-triazole, Sigma-Aldrich, WI, USA), and was measured at $540 \mathrm{~nm}$ (Trasviña-Arenas et al. 2013). The CAT activity was calculated using a standard curve calibrated with known formaldehyde concentrations $\left(r^{2}=0.9993\right)$ and the results are expressed in unit $\min ^{-1} \mathrm{mg}$ protein $^{-1}$. 
GPx and SOD activities were measured using assay kits (Cayman Chemical Company Inc., MI, USA). These enzyme activities were determined according to the assay protocols. Specific activities of the enzymes are expressed in unit $\min ^{-1} \mathrm{mg}$ protein ${ }^{-1}$.

Ten shrimp per treatment group were euthanized by immersion in cold water until no movement of their appendages was observed. The shrimp were wiped to remove excess water and then individually weighed. The hepatopancreas was immediately dissected and weighed to determine the hepato-somatic index (HSI) as follows:

HSI $=100 \times[$ hepatopancreas weight $(\mathrm{g}) /$ shrimp body weight $(\mathrm{g})]$.

Lipid peroxidation (LPO) in the hepatopancreas was determined as thiobarbituric acid reactive substances (TBARS) level, based on the reaction of 2-thiobarbituric acid (TBA) with malondialdehyde (MDA). Measurements of LPO were conducted according to the method of Senphan and Benjakul (2012). Tissue samples $(\sim 0.3 \mathrm{~g})(n=10 /$ feed group) were blended and mixed with TBA working solution $(0.375 \%(\mathrm{w} / \mathrm{v})$ TBA (Sigma-Aldrich, Steinheim, Germany), 15\% (w/v) trichloroacetic acid (TCA) and 0.25 M HCl). The homogenized samples were heated in a $95{ }^{\circ} \mathrm{C}$ shaking water bath for $10 \mathrm{~min}$, and were then cooled with running tap water, and centrifuged at $4800 \times g$ for $10 \mathrm{~min}$ at $4{ }^{\circ} \mathrm{C}$. The supernatant was measured by a microplate reader at $532 \mathrm{~nm}$. MDA concentration in each sample was calculated from an eight-point standard curve $\left(r^{2}=0.9997\right)$ for 1,1,3,3-tetramethoxypropane (TEP) (Sigma-Aldrich, Steinheim, Germany) calibration standards, and the results are expressed in nmols MDA per gram of wet weight tissue.

Digestive enzyme analysis

The activities of digestive enzymes in shrimp hepatopancreas were determined at the termination of feeding study. The hepatopancreas ( $n=10 /$ treatment) was dissected and collected, weighed and homogenized with $50 \mathrm{mM}$ Tris- $\mathrm{HCl}$. The homogenized mixture was then centrifuged at $12,879 \times g$ for 15 min at $4{ }^{\circ} \mathrm{C}$. For the different enzyme analyzes, the supernatant was aliquoted in triplicate into cryogenic vials, to determine total protease, trypsin, and amylase. The vials were kept at $-70{ }^{\circ} \mathrm{C}$ until analysis.

Total proteinase activity was estimated as suggested by Ávila-Villa et al. (2012). Briefly, $20 \mu \mathrm{L}$ of sample extract was added in a test tube, then $500 \mu \mathrm{L}$ of $2 \%$ azocasein (Sigma-Aldrich, MO, USA) and $240 \mu \mathrm{L}$ of $50 \mathrm{mM}$ Tris- $\mathrm{HCl}$ buffer ( $\mathrm{pH} 7.5$ ) were added and mixed well in a vortex shaker. The mixture was incubated at room temperature for $30 \mathrm{~min}$. The reaction was stopped by adding $500 \mu \mathrm{L}$ of $20 \%$ TCA and then the sample was centrifuged at $6500 \times g$ for $5 \mathrm{~min}$. The supernatant was collected and measured in a microplate reader at $450 \mathrm{~nm}$. The activity is expressed in unit $\mathrm{mg} \mathrm{protein}^{-1}$. One unit of protease activity was defined as the amount of enzyme that catalyzes the release of the azo dye, causing the change in absorbance at $450 \mathrm{~nm}$ of 0.001 per minute under assay conditions.

Trypsin activity was estimated by the method described by García-Carreño and Haard (1994) with some modification. Benzoil-Arg- $p$-nitroanilide (BAPNA) (Sigma-Aldrich, Tokyo, Japan) was used as the substrate. The analysis was started by mixing $30 \mu \mathrm{L}$ of the sample extract with $320 \mu \mathrm{L}$ of $0.1 \mathrm{mM}$ BAPNA. After incubating for $20 \mathrm{~min}$ at $37^{\circ} \mathrm{C}$, the reaction was stopped by adding $50 \mu \mathrm{L}$ of $20 \%$ TCA, and the product was then centrifuged at $6500 \times g$ for $5 \mathrm{~min}$. The absorbance was read in a microplate reader at $410 \mathrm{~nm}$. Trypsin activity was estimated as $[(\mathrm{Abs} 410 \mathrm{~nm} / \mathrm{min} \times$ volume $(\mathrm{mL})$ of reaction mixture $\times$ dilution factor $) /(8800 \times$ volume $(\mathrm{mL})$ of enzyme $\times \mathrm{mg}$ protein of the sample extract)], where the constant 8800 is the extinction coefficient of $p$-nitroanilide. The activity is expressed in unit $\mathrm{mg}_{\text {protein }}{ }^{-1}$. One unit of trypsin activity was defined as $1 \mu \mathrm{mol}$ of $p$-nitroanilide released per minute under the specified conditions.

Amylase activity was determined with the 3,5-dinitrosalicylic acid (DNS) method (Rick and Stegbauer 1974) using $1 \%$ (w/v) starch solution as substrate. First, $100 \mu \mathrm{L}$ of the sample extract was placed in a test tube and then $100 \mu \mathrm{L}$ of substrate and $1.8 \mathrm{~mL}$ phosphate buffer $(0.1 \mathrm{M}, \mathrm{pH} 7)$ were added and mixed thoroughly. The mixture was incubated at $37{ }^{\circ} \mathrm{C}$ for $30 \mathrm{~min}$. The reaction was stopped by adding $2 \mathrm{~mL}$ DNS (SigmaAldrich, Bangalore, India), and then the sample was heated in boiling water for 5 min. After cooling with running tap water, the reaction mixture was diluted with distilled water and measured by microplate reader at $540 \mathrm{~nm}$. Amylase activity was calculated from a standard curve for maltose. One unit of enzyme activity was defined as $1 \mathrm{mg}$ of maltose liberated in $1 \mathrm{~min}$ at $37^{\circ} \mathrm{C}$. 
Histological examination

At the end of the feeding trial, ten shrimp per treatment group were euthanized by immersion in cold water. Shrimp heads were collected, cut in half lengthwise, and then immediately preserved in Davidson's fixative (Lightner et al. 2009). After fixation, samples were embedded in cassette molds and were processed overnight by automatic tissue processors (Leica, Nussloch, Germany). The samples were then embedded into paraffin blocks and cut to 3- $\mu$ m thickness with a sliding microtome (R. Jung AG, Heidelberg, Germany). The sections were stained with haematoxylin and eosin (H\&E) (Bancroft 1967; Humason 1979). The stained sections were examined under a light microscope (Olympus CH30, Olympus Corporation, Tokyo, Japan), and then a selected area in the stained section was imaged with an Olympus DP71 digital camera and software (Olympus Corporation, Tokyo, Japan).

Statistical analysis

The data are presented as mean \pm standard deviation (SD). The statistical analyzes used SPSS version 11.5 for Windows. One-way analysis of variance (ANOVA) was used for comparison between groups, and the means were compared with LSD post hoc method. Differences were considered statistically significant at $p<0.05$.

\section{Results}

Growth performance and feed efficiency

Survival rate of shrimp fed the control diet was significantly higher than that of shrimp fed the MEL alone diet $(p<0.05)$, but these were not significantly different from the other treatments $(p>0.05)$ (Table 3. Furthermore, the diets including MEL or CYA (singly or in combination) did not cause any obvious external abnormality. However, the FCR was significantly higher $(p<0.05)$ in shrimp fed the diets $2-7$ compared to those fed the control diet (Table 3). Shrimp receiving high doses of MEL (alone or with CYA, diets 4-6) had significantly $(p<0.05)$ lower feed consumption than that of shrimp fed the control diet. The growth performances are shown in Table 3. The diets $2-7$ gave significantly $(p<0.05)$ lower final body weight, ADG, and SGR than the control treatment.

Proximate composition of whole shrimp body

The proximal composition of the whole shrimp bodies is presented in Table 4. At the end of feeding trial, shrimp fed diets supplemented with MEL and CYA, either singly or combined at various dose levels, had significant $(p<0.05)$ effects on the whole body composition, including dry matter, crude protein, and crude lipid, deviating from the control group. It was noted that protein in the shrimp carcass was significantly $(p<0.05)$ elevated, whereas lipid content was significantly $(p<0.05)$ reduced by the actual dietary treatments. However, crude ash was not significantly $(p>0.05)$ different between the treatments.

Hemolymph analysis and immunological response

Hemolymph analyzes for the different treatment groups are presented in Table 5. Relative to the control group, the total hemocyte counts (THC) of shrimp receiving MEL were significantly decreased $(p<0.05)$, but no significant $(p>0.05)$ difference was caused by CYA alone in the diet. PO activity in the shrimp fed combined doses of MEL and CYA increased from the $5+5$ to the $10+10 \mathrm{~g} \mathrm{~kg}^{-1}$ diet group, and MEL dosing alone at $10 \mathrm{~g} \mathrm{~kg}^{-1}$ diet gave significantly $(p<0.05)$ lower PO than the control diet. However, no significant $(p>0.05)$ effect was found in shrimp fed $2.5+2.5 \mathrm{~g} \mathrm{~kg}^{-1}$ diet or with CYA dosing alone at $10 \mathrm{~g} \mathrm{~kg}^{-1} \mathrm{diet}$ Respiratory burst activity in shrimp fed the control diet was found significantly $(p<0.05)$ higher than with the actual treatments. Significantly $(p<0.05)$ reduced lysozyme activity was found in the shrimp fed $10+10 \mathrm{~g}$ $\mathrm{kg}^{-1}$ diet combined dose of MEL and CYA, or MEL alone at $10 \mathrm{~g} \mathrm{~kg}^{-1}$ diet. 


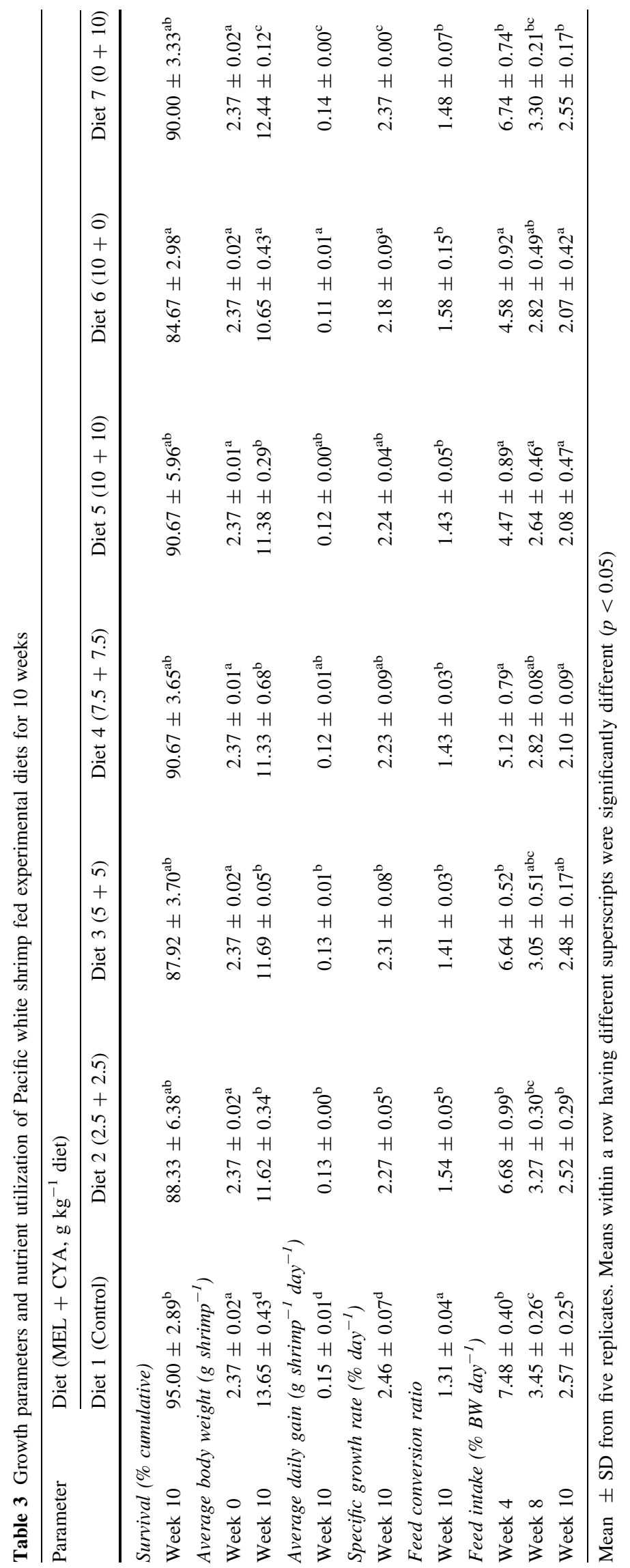




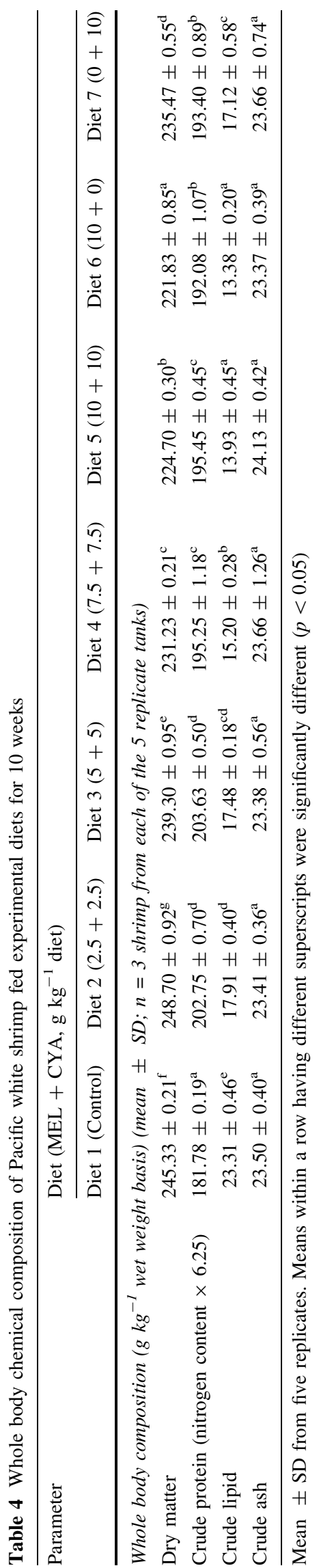




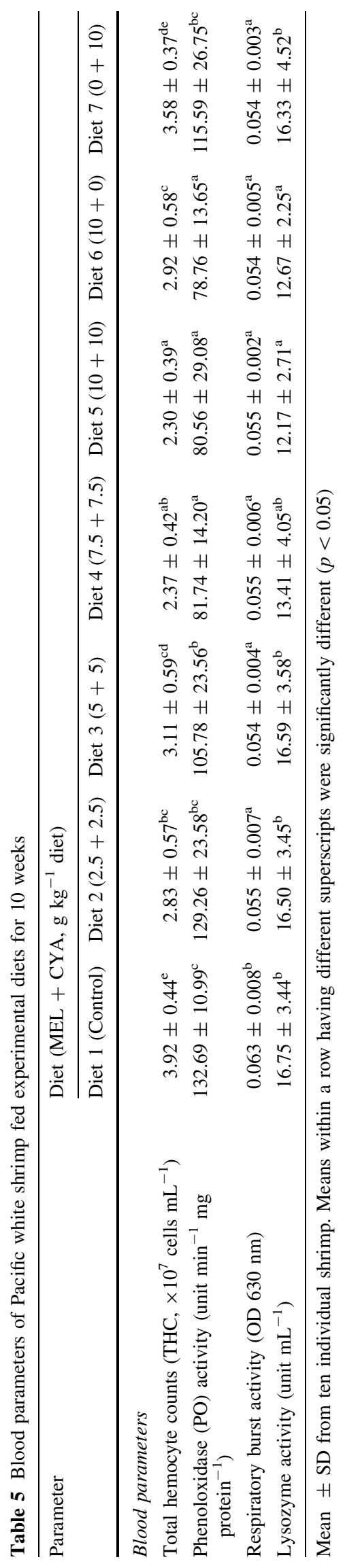


Antioxidant enzyme activities

The antioxidant enzyme activities are presented in Table 6. Catalase (CAT) activity in both hepatopancreas and gill of shrimp treated with MEL+CYA doses of $5+5$ or $10+10 \mathrm{~g} \mathrm{~kg}^{-1}$ diet, or with MEL alone at $10 \mathrm{~g}$ $\mathrm{kg}^{-1}$ diet, were significantly $(p<0.05)$ lower than with the control diet. Glutathione peroxidase (GPx) activity in hepatopancreas was significantly $(p<0.05)$ lower in shrimp fed MEL+CYA at $7.5+7.5$ or $10+10 \mathrm{~g} \mathrm{~kg}^{-1}$ diet, or with MEL alone at $10 \mathrm{~g} \mathrm{~kg}^{-1}$ diet compared to those fed the control diet, whereas the GPx activity in gill was significantly $(p<0.05)$ affected only in the shrimp fed $10+10 \mathrm{~g} \mathrm{~kg}^{-1}$ diet combined dose of MEL+CYA or the MEL at $10 \mathrm{~g} \mathrm{~kg}^{-1}$ diet. Superoxide dismutase (SOD) activities in both hepatopancreas and gill were significantly $(p<0.05)$ lower in shrimp fed the MEL+CYA dose at $10+10 \mathrm{~g}$ $\mathrm{kg}^{-1}$ diet, or MEL alone at $10 \mathrm{~g} \mathrm{~kg}^{-1}$ diet.

Lipid peroxidation (LPO) in the hepatopancreas was significantly $(p<0.05)$ increased in the shrimp that were fed the combination MEL+CYA, increasing from $7.5+7.5$ to $10+10 \mathrm{~g} \mathrm{~kg}^{-1}$ diet dose level, or MEL alone at $10 \mathrm{~g} \mathrm{~kg}^{-1}$ diet (Table 6). The hepato-somatic index (HSI) in shrimp receiving combined dose that increased from the $7.5+7.5$ to the $10+10 \mathrm{~g} \mathrm{~kg}^{-1}$ diet dose level, giving a significantly $(p<0.05)$ lower index than the control diet (Table 6).

Digestive enzyme activities

Digestive enzyme activities in hepatopancreas are presented in Table 6. Compared to the control group (diet $1)$, total protease and trypsin activities were significantly lower $(p<0.05)$ in the shrimp fed combined MEL+CYA doses or the CYA at $10 \mathrm{~g} \mathrm{~kg}^{-1}$ diet. Furthermore, the shrimp fed combined MEL+CYA doses from $7.5+7.5$ to $10+10 \mathrm{~g} \mathrm{~kg}^{-1}$ diet had significantly $(p<0.05)$ reduced amylase activity. Total protease, trypsin and amylase were affected by MEL alone at $10 \mathrm{~g} \mathrm{~kg}^{-1}$ diet $(p<0.05)$.

\section{Histopathological changes}

Histopathological alterations in the hepatopancreas of shrimp after 10-week dietary treatments containing MEL and CYA singly or in combination are presented in Fig. 1. The normal cells of hepatopancreas, tubular morphology and numbers of B-(blister-like) cells, F-(fibrillar) cells, and R-(resorptive/absorptive) cells were found in the control group (Fig. 1a). Severe atrophic changes, degenerative hepatopancreatic tubules, and lacking B-, F- and R-cells were detected in shrimp fed combined MEL+CYA doses from $2.5+2.5$ to $10+10 \mathrm{~g} \mathrm{~kg}^{-1}$ diet (Fig. 1b-d). With MEL or CYA singly, degenerated and shrunken hepatopancreatic tubules were observed (Fig. 1e-f).

\section{Discussion}

Since the pet food crisis in 2007, MEL and its analogs including CYA have been illegally used to elevate the apparent total protein content, thereby adulterating certain protein-rich feed ingredients (Brown et al. 2007; Puschner et al. 2007; Stine et al. 2011). There have been reports of MEL and related analogs in feed ingredients and in animal feeds for swine, poultry, fish, and shrimp (Andersen et al. 2008; Stine et al. 2012). Negative effects from such adulteration in animals have been reported, having as symptoms nephrotoxicity, growth retardation, discoloration, and immune suppression (Baynes et al. 2008; Reimschuessel et al. 2008, 2010; Xue et al. 2011; Phromkunthong et al. 2013, 2015a, b). However, data relating to the toxicity in penaeid shrimp of MEL or CYA exposures is limited. In this study, the toxicity of MEL and CYA to Pacific white shrimp was examined over 10 weeks of laboratory conditions. The results from this study demonstrate depressed growth and negative effects by dietary MEL-CYA. In the present study, combined MEL+CYA from $2.5+2.5$ to $10+10 \mathrm{~g} \mathrm{~kg}^{-1}$ diet had negative effects on shrimp growth and feed conversion ratio. As previously reported, growth depression is a clinical sign of the toxicity of combined MEL and CYA that has been reported in mice (Lv et al. 2013) and in some farmed fish species, such as red tilapia (Phromkunthong et al. 2013, 2015a) and Asian sea bass (Phromkunthong et al. 2015b). In addition, the combination of MEL and CYA is more toxic than exposure to either chemical separately (Karbiwnyk et al. 2010). However, in this 


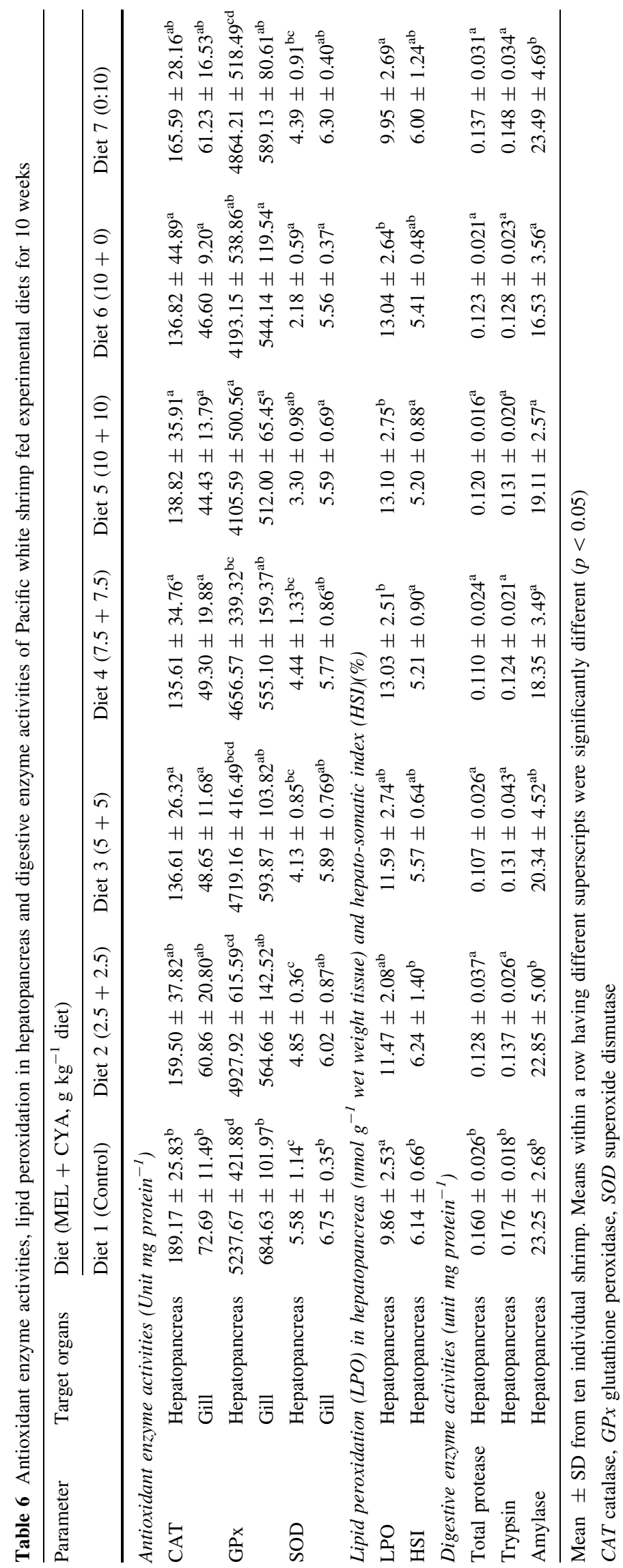




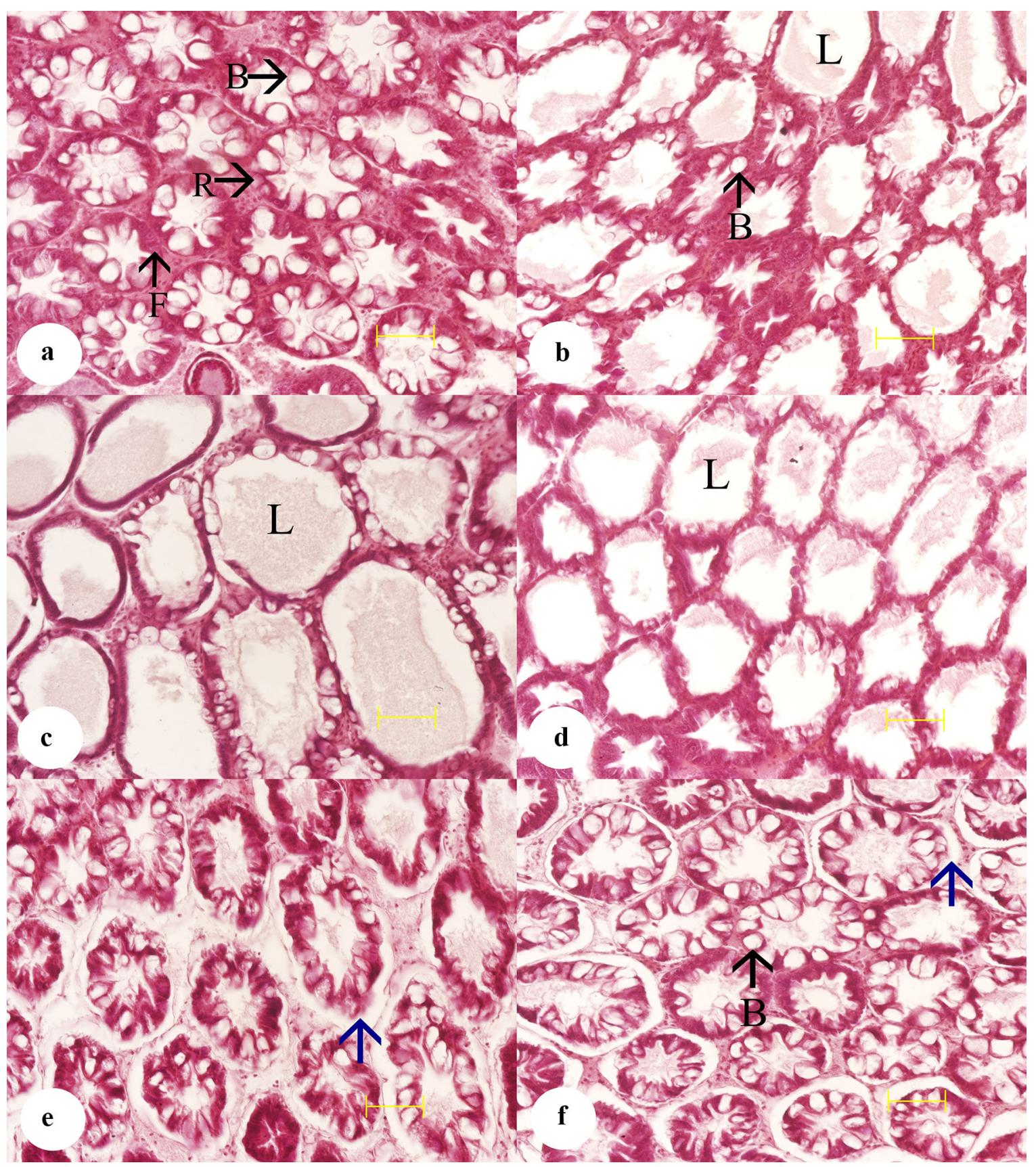

Fig.1 Photomicrographs of haematoxylin and eosin (H\&E) stained sections of hepatopancreas from Pacific white shrimp fed diets containing various levels of MEL and/or CYA for 10 weeks. a The sections of hepatopancreatic tubules of shrimp fed the control diet showing normal structure of R ("restzellen") cells, F ("fibrillenzellen" or fibrous) cells and B ("blasenzenllen") cells (magnification $\times 200$; scale bar $100 \mu \mathrm{m}$ ); $\mathbf{b}$ atrophic changes and degenerated tubules were observed in shrimp fed a combination MEL+CYA at $2.5+2.5 \mathrm{~g} \mathrm{~kg}^{-1}$ diet $(\mathrm{L}=$ lumen, magnification $\times 200$; scale bar $100 \mu \mathrm{m})$; $\mathbf{c}$ shrimp receiving MEL+CYA at $5+5 \mathrm{~g} \mathrm{~kg}^{-1}$ diet showed severe atrophic changes of hepatopancreatic tubule ( $\mathrm{L}=$ lumen, magnification $\times 200$; scale bar $100 \mu \mathrm{m}) ; \mathbf{d}$ shrimp receiving MEL+CYA at $10+10 \mathrm{~g} \mathrm{~kg}^{-1}$ diet showed degenerative changes in the hepatopancreas ( $\mathrm{L}=$ lumen, magnification $\times 200$; scale bar $100 \mu \mathrm{m}$ ); degenerated and shrunken hepatopancreatic tubules (blue arrow) were observed in shrimp receiving MEL alone $\left(10+0 \mathrm{~g} \mathrm{~kg}^{-1}\right.$ diet) (e) or CYA alone $\left(0+10 \mathrm{~g} \mathrm{~kg}^{-1}\right.$ diet) (f) (magnification $\times 200$; scale bar $100 \mu \mathrm{m})$

study, the growth performance of shrimp receiving MEL alone at $10 \mathrm{~g} \mathrm{~kg}^{-1}$ diet was significantly lower than in the control group. In another experimental study, the growth performance and feed utilization of black tiger shrimp (Penaeus monodon) were not significantly affected by dietary MEL doses ranging from 0.005 to $0.5 \mathrm{~g}$ 
$\mathrm{kg}^{-1}$ diet for 11 weeks (Samranrat et al. 2011). Therefore, the safe dose level for Pacific white shrimp should not exceed $0.5 \mathrm{~g} \mathrm{~kg}^{-1}$ diet. Furthermore, the results in this current study show that shrimp exposure to dietary CYA decreased growth. Data on adulteration by CYA alone in shrimp feed is limited. In our previous study, Phromkunthong et al. (2015b) reported no significant difference in the growth of Asian seabass between receiving CYA alone and control. That the reported results tend to differ qualitatively suggests that sensitivity to these chemicals strongly depends on the species.

In fish and higher animals, the toxic effects of MEL and CYA singly or in combination are directly related to kidney pathology and functions (Dorne et al. 2013). One possible reason for the growth depression and poor feed utilization is directly linked to the dysfunction of hepatopancreas, which is an important organ for several metabolic functions, including nutrient digestion, absorption, and storage, in crustaceans (Burgos-Hernández et al. 2005; Zhao et al. 2017). Activities of the digestive enzymes are indicative of the feeding habits, diet composition, digestive functions, and nutrient utilization, which directly relate to shrimp growth ( $\mathrm{Li}$ et al. 2008a; Zokaeifar et al. 2012; Duan et al. 2017). The function of digestive enzymes in shrimp can be influenced by diet composition (CórdovaMurueta and García-Carreño 2002; Song et al. 2017). In the present study, the reductions of digestive enzyme activities (especially of protease) were marked in shrimp receiving MEL alone or in combination with CYA. However, prior reports on effects of MEL+CYA on the digestive enzymes in shrimp are limited. In some cases, exposure to toxic substances (e.g., heavy metals, pesticides and toxins) can adversely affect the digestive function (Li et al. 2008b; Chiodi Boudet et al. 2015). Moreover, our study found that shrimp dosed combined MEL+CYA up to $7.5+7.5 \mathrm{~g} \mathrm{~kg}^{-1}$ diet or MEL alone had significantly decreased enzyme activities, indicating poor nutrient absorption and storage. Similar to our results, Seebaugh et al. (2011) reported a significant decrease in digestive enzyme activities of shrimp that was related to reduced food ingestion.

Furthermore, hepatopancreas is an important organ for the chemical detoxification of shrimp, and is sensitive to stress responses (Bautista et al. 1994; Yu et al. 2016). Exposure to chronic stress elevates the generation of reactive oxygen species (ROS) leading to an imbalance between ROS and antioxidant enzyme activities, which results in cellular damage from oxidative stress (Yang et al. 2010; An et al. 2015; Lee et al. 2016). In this study, the activities of CAT, GPx and SOD were significantly decreased in both gill and hepatopancreas of shrimp fed the highest combination level of MEL-CYA (10:10 $\mathrm{g} \mathrm{kg}^{-1}$ diet) or MEL alone $\left(10 \mathrm{~g} \mathrm{~kg}^{-1}\right.$ diet). This suggests that the main toxic effects of MEL and CYA take place via oxidative stress, resulting in cellular damage and dysfunction of the related detoxification organs in shrimp, which adversely affects growth ( $\mathrm{Li}$ et al. 2008a). Evidence of oxidative stress induced by the combination of MEL and CYA in diet has been reported by Lv et al. (2013), who found that the activity of SOD in mouse kidney was decreased after 13-week exposure to a mixture of MEL and CYA. In addition, You et al. (2012) found significantly decreased total antioxidant capacity (T-AOC) and SOD activity in mouse testes after a mixture of MEL and CYA was orally administered for 28 days.

Malondialdehyde (MDA) is among the main lipid peroxidation indicators in cells and tissues, and increased MDA levels indicate elevated oxidative stress (Zenteno-Savín et al. 2006; Liu et al. 2011; Chiodi Boudet et al. 2015; Liang et al. 2016). In this study, our results showed that the MDA content in hepatopancreas of shrimp fed combined MEL+CYA up to $7.5+7.5 \mathrm{~g} \mathrm{~kg}^{-1}$ diet, or MEL alone, was significantly elevated from that with the control diet. This indicates oxidative damage induced by these chemicals. A similar result was also reported by Lee et al. (2016), who found elevated lipid peroxidation in mouse kidney induced by co-exposure to MEL and CYA, which also caused apoptotic changes in the renal tubular cells and suppressed antioxidant enzyme activities. In melamine-exposed animals, An et al. (2015) reported increased MDA levels in the hippocampus after oral administration of MEL to male Wistar rats (dosage $300 \mathrm{mg} \mathrm{kg}^{-1}$ animal day ${ }^{-1}$ for 28 days). Moreover, there are several reports on significantly increased MDA level by stress in many aquatic animals. Liang et al. (2016) reported that MDA levels in hepatopancreas significantly increased after exposure to ammonia for $96 \mathrm{~h}$.

The hepato-somatic index (HSI) is an important parameter indicative of hepatopancreas conditions, as well as of glycogen reserve. In the present study, HSI was significantly decreased in shrimp fed MEL alone or in combination with CYA at $7.5+7.5$ or $10+10 \mathrm{~g} \mathrm{~kg}^{-1}$ diet, relative to the control group. This suggests that long-term diet supplementation with MEL and CYA to shrimp in their feed caused extra energy expenditures in detoxification. Moreover, reduced energy storage may have been induced indirectly through anorexia caused by MEL or CYA (Khalil et al. 2017).

Hemolymph is an indicator of shrimp performance, health status, and rearing conditions, and is closely related to the innate immune system ( $\mathrm{Li}$ et al. 2008a; Chen et al. 2015; Qiu et al. 2016). In crustaceans, THC and PO system play important roles in the immune system, especially in shrimp (Sritunyalucksana and 
Söderhäll 2000; Li et al. 2008a; Wanlem et al. 2011). In the present study, the immune parameters in shrimp fed diets supplemented with MEL alone or in combination with CYA at the highest dose $\left(10+10 \mathrm{~g} \mathrm{~kg}^{-1}\right.$ diet) had decreased THC and PO activities. Moreover, Yin et al. (2016) reported that MEL alone or its combination with CYA appeared to be toxic to the immune system of mice.

The results from this study indicate that crude protein content in shrimp treated with a combination of MEL and CYA, or either of these singly, was significantly increased as compared to control after 10 weeks of feeding. In general, the protein content in the whole body of an animal, including fish and shrimp, is determined by the dietary protein levels and their quality, digestibility, and feeding (Halver and Hardy 2002; Kureshy and Davis 2002). The increased protein retention suggests improved protein utilization positively affecting growth performance (Glencross et al. 2007). In our current study, in contrast to growth, increased protein content was recorded in shrimp treated with MEL and CYA singly or in combination. These results agree with previous reports regarding red tilapia (Phromkunthong et al. 2013, 2015a) and Asian seabass (Phromkunthong et al. 2015b), indicating that the protein content in the whole body and in various parts of fish, such as filet or viscera, directly increased in response to dietary MEL+CYA. Therefore, the increased protein content of shrimp whole body in the MEL+CYA treated group may be attributed to the accumulation of nitrogen from these substances. Karbiwnyk et al. (2010) reported accumulation of CYA in edible tissues at 0.767 and $0.406 \mathrm{mg} \mathrm{kg}^{-1}$ in shrimp fed with 1666 or $3333 \mathrm{mg} \mathrm{kg}^{-1}$ diet CYA (approximately 55 and $124 \mathrm{mg}$ $\mathrm{kg}^{-1}$ bodyweight) in their diet, respectively. However, the behavior of these substances in a shrimp body is not well-understood; the pharmacokinetics/dynamics need to be further studied.

Histological analysis of hepatopancreas has been used as a practical means for assessing the nutritional condition and toxic substance accumulation in the shrimp (Qiu et al. 2016). According to our current study, MEL and CYA directly affect the hepatopancreas. In fish, the presence of melamine-cyanurate crystals in kidney is the main pathological sign of chronic exposure to these compounds, and leads to renal nephropathy (Reimschuessel et al. 2010; Pirarat et al. 2012; Phromkunthong et al. 2015a, b). Previously, in Thailand, "water sac syndrome" or "big head syndrome" have been claimed to be pathological signs in shrimp exposed to MEL and CYA contamination (Limsuwan et al. 2009; WHO 2009). Similar results have been reported by Lightner et al. (2009), who found that shrimp fed MEL and CYA in their diets could have insoluble crystals in the antennal glands, obstructing and impairing the excretory system and causing swollen cephalothorax. Moreover, the results of our current study indicate severe histopathological alterations including severe atrophic changes and necrosis in hepatopancreas of shrimp exposed to MEL and CYA for 10 weeks.

\section{Conclusion}

This study investigated the responses of Pacific white shrimp, L. vannamei, to MEL and CYA exposures either singly or in combination to understand the mechanisms of toxicity. Results of the present study indicate that growth performance and feed utilization were negatively affected by MEL and CYA exposure, with reductions in mean weight gain, average daily gain, specific growth rate and an increase in the feed conversion ratio. Exposure to these substances also damaged the cells of hepatopancreas, leading to the generation of oxidative stress, increased lipid peroxidation and decreased antioxidant and immune responses, which demonstrate that the hepatopancreas of shrimp is sensitive to MEL and CYA. In summary, our results provide some basic information for a toxicological risk assessment of MEL and CYA in the context of shrimp farming. It is noted that further studies should assess the accumulation of these substances in the edible part of shrimp to address public concerns of health risks to consumers.

Acknowledgements We would like to acknowledge the Higher Education Research Promotion and National Research University Project of Thailand, Office of the Higher Education Commission (Grant no.: NAT540528S) for the grant support. We also gratefully acknowledge the Publication Clinic and Associate Professor Dr. Seppo Karrila, Research and Development Office, Prince of Songkla University, for help in manuscript preparation. Thanks are also due to the Prince of Songkla University for their partial financial support.

Open Access This article is distributed under the terms of the Creative Commons Attribution 4.0 International License (http:// creativecommons.org/licenses/by/4.0/), which permits unrestricted use, distribution, and reproduction in any medium, provided you give appropriate credit to the original author(s) and the source, provide a link to the Creative Commons license, and indicate if changes were made. 


\section{References}

Amaya E, Davis DA, Rouse DB (2007) Alternative diets for the Pacific white shrimp Litopenaeus vannamei. Aquaculture 262:419-425

An L, Fu J, Zhang T (2015) Reversible effects of vitamins C and E combination on cognitive deficits and oxidative stress in the hippocampus of melamine-exposed rats. Pharmacol Biochem Behav 132:152-159

Andersen WC, Turnipseed SB, Karbiwnyk CM, Clark SB, Madson MR, Gieseker CM, Miller RA, Rummel NG, Reimschuessel R (2008) Determination and confirmation of melamine residues in catfish, trout, tilapia, salmon, and shrimp by liquid chromatography with tandem mass spectrometry. J Agric Food Chem 56:4340-4347

AOAC (Association of Official Analytical Chemists) (1995) Official methods of analysis of AOAC International, 16th edn. Association of Analytical Communities, Arlington

Ávila-Villa LA, Fimbres-Olivarria D, García-Sánchez G, Gollas-Galván T, Hernández-López J, Martínez-Porchas M (2012) Physiological and immune responses of white shrimp (Litopenaeus vannamei) infected with necrotizing hepatopancreatitis bacterium. Aquaculture 324-325:14-19

Bancroft JD (1967) Histochemical techniques. Butterworths, London

Bautista MN, Lavilla-Pitogo CR, Subosa PF, Begino ET (1994) Aflatoxin B1 contamination of shrimp feeds and its effects on growth and hepatopancreas and pre-adult Penaeus monodon. J Sci Food Agric 65:5-11

Baynes RE, Smith G, Mason SE, Barrett E, Barlow BM, Riviere JE (2008) Pharmacokinetics of melamine in pigs following intravenous administration. Food Chem Toxicol 46:1196-1200

Bradford MM (1976) A rapid and sensitive method for the quantitation of micro-gram quantities of protein using the principle of protein-dye binding. Anal Biochem 72:248-254

Brown CA, Jeong KS, Poppenga RH, Puschner B, Miller DM, Ellis AE, Kang KI, Sum S, Cistola AM, Brown SA (2007) Outbreaks of renal failure associated with melamine and cyanuric acid in dogs and cats in 2004 and 2007. J Vet Diagn Invest 19:525-531

Burgos-Hernández A, Farias SI, Torres-Arreola W, Ezquerra-Brauer JM (2005) In vitro studies of the effects of aflatoxin B1 and fumonisin B1 on trypsin-like and collagenase-like activity from the hepatopancreas of white shrimp (Litopenaeus vannamei). Aquaculture 250:399-410

Byrne J (2016) Thai authorities find melamine in imported feed. https://www.feednavigator.com/Article/2016/10/27/Thaiauthorities-find-melamine-in-imported-feed. Accessed 5 Jan 2019

Carvalho RAPLFde, Ota RH, Kadry VO, Tacon AGJ, Lemos D, (2016) Apparent digestibility of protein, energy and amino acids of six protein sources included at three levels in diets for juvenile white shrimp Litopenaeus vannamei reared in high performance conditions. Aquaculture 465:223-234

Casu A, Camino G, De Giorgi M, Flath D, Morone V, Zenoni R (1997) Fire-retardant mechanistic aspects of melamine cyanurate in polyamide copolymer. Polym Degrad Stab 58:297-302

CCAC (Canadian Council on Animal Care) (2005) The CCAC guidelines on: the care and use of fish in research, teaching and testing. CCAC, Ottawa

Chen YY, Chen JC, Lin YC, Yeh ST, Huang CL (2015) White shrimp Litopenaeus vannamei that have received Gracilaria tenuistipitata extract show early recovery of immune parameters after ammonia stressing. Mar Drugs 13:3606-3624

Chiodi Boudet LN, Polizzi P, Romero MB, Robles A, Marcovecchio JE, Gerpe MS (2015) Histopathological and biochemical evidence of hepatopancreatic toxicity caused by cadmium in white shrimp, Palaemonetes argentinus. Ecotoxicol Environ Saf 113:231-240

Córdova-Murueta JH, García-Carreño FL (2002) Nutritive value of squid and hydrolyzed protein supplement in shrimp feed. Aquaculture 210:371-384

Dorne JL, Doerge DR, Vandenbroeck M, Fink-Gremmels J, Mennes W, Knutsen HK, Vernazza F, Castle L, Edler L, Benford D (2013) Recent advances in the risk assessment of melamine and cyanuric acid in animal feed. Toxicol Appl Pharmacol 270:218-229

Duan Y, Zhang Y, Dong H, Zheng X, Wang Y, Li H, Liu Q, Zhang J (2017) Effect of dietary poly- $\beta$-hydroxybutyrate (PHB) on growth performance, intestinal health status and body composition of Pacific white shrimp Litopenaeus vannamei (Boone, 1931). Fish Shellfish Immunol 60:520-528

Ehling S, Tefera S, Ho IP (2007) High-performance liquid chromatographic method for the simultaneous detection of the adulteration of cereal flours with melamine and related triazine by-products ammeline, ammelide, and cyanuric acid. Food Addit Contam 24:1319-1325

Ellis AE (1990) Lysozyme assay. In: Stolen JS, Fletcher TC, Anderson DP, Roberson BS, Muiswinkel WB (eds) Technique in fish immunology. SOS Publications, Fair Haven, pp 101-103

European Commission (2013) Commission Regulation (EU) No 107/2013 of 5 February 2013 amending Annex I to Directive 2002/32/EC of the European Parliament and of the Council as regards maximum levels for melamine in canned pet food. Official Journal of the European Union, Brussels.

FAO (Food and Agriculture Organization of the United Nations) (2016) The state of world fisheries and aquaculture 2016. FAO, Rome

García-Carreño FL, Haard N (1994) Preparation of an exopeptidase enriched fraction from the hepatopancreas of decapods. Process Biochem 29:663-670

Glencross BD, Booth M, Allan GL (2007) A feed is only as good as its ingredients: a review of ingredient evaluation strategies for aquaculture feeds. Aquac Nutr 13:17-34

Halver JE, Hardy RW (2002) Fish nutrition. Academic Press, San Diego

Hsu SW, Chen JC (2007) The immune response of white shrimp Penaeus vannamei and its susceptibility to Vibrio alginolyticus under sulfide stress. Aquaculture 271:61-69 
Humason GL (1979) Animal tissue techniques. W.H Freeman and Company, Francisco

JAVMA (2007) Melamine adulterates component of pellet feeds. J Am Vet Med Assoc 231:17

Karbiwnyk CM, Williams RR, Andersen WC, Turnipseed SB, Madson MR, Miller KE, Reimschuessel R (2010) Bioaccumulation of cyanuric acid in edible tissues of shrimp following experimental feeding. Food Addit Contam Part A Chem Anal Control Expos Risk Assess 27:1658-1664

Khalil SR, Awad A, Ali SA (2017) Melamine and/or formaldehyde exposures affect steroidogenesis via alteration of StAR protein and testosterone synthetic enzyme expression in male mice. Environ Toxicol Pharmacol 50:136-144

Kim J, Nhut T, Hai T, Ra C (2011) Effect of dietary essential oils on growth, feed utilization and meat yields of white leg shrimp L. vannamei. Asian Austral J Anim Sci 24:1136-1141

Kureshy N, Davis DA (2002) Protein requirement for maintenance and maximum weight gain for the Pacific white shrimp, Litopenaeus vannamei. Aquaculture 204:125-143

Lee IC, Ko JW, Park SH, Shin IS, Moon C, Kim SH, Kim YB, Kim JC (2016) Melamine and cyanuric acid co-exposure causes renal dysfunction and structural damage via MAPKs and mitochondrial signaling. Food Chem Toxicol 96:254-262

Li E, Chen L, Zeng C, Yu N, Xiong Z, Chen X, Qin JG (2008a) Comparison of digestive and antioxidant enzymes activities, haemolymph oxyhemocyanin contents and hepatopancreas histology of white shrimp, Litopenaeus vannamei, at various salinities. Aquaculture 274:80-86

Li N, Zhao Y, Yang J (2008b) Effects of water-borne copper on digestive and metabolic enzymes of the giant freshwater prawn Macrobrachium rosenbergii. Arch Environ Contam Toxicol 55:86-93

Liang Z, Liu R, Zhao D, Wang L, Sun M, Wang M, Song L (2016) Ammonia exposure induces oxidative stress, endoplasmic reticulum stress and apoptosis in hepatopancreas of pacific white shrimp (Litopenaeus vannamei). Fish Shellfish Immunol 54:523-528

Lightner DV, Pantoja CR, Redman RM, Hasson KW, Menon JP (2009) Case reports of melamine-induced pathology in penaeid shrimp fed adulterated feeds. Dis Aquat Organ 86:107-112

Limsuwan C, Chuchird N, Prasertsri S, Wongmaneeprateep S, Laisutisan K, Wiriyapattanasub P, Limhang K (2009) Gross and histopathological changes of Pacific white shrimp (Litopenaeus vannamei) experimentally induced with contaminated of melamine plus cyanuric acid in pelleted feed. In: Proceedings of 47th Kasetsart University Annual Conference: Fisheries. 2009 March 17-20; Bangkok: Kasetsart University (article in thai)

Liu CH, Yeh ST, Cheng SY, Chen JC (2004) The immune response of the white shrimp Litopenaeus vannamei and its susceptibility to Vibrio infection in relation with the moult cycle. Fish Shellfish Immunol 16:151-161

Liu XL, Xi QY, Yang L, Li HY, Jiang QY, Shu G, Wang SB, Gao P, Zhu XT, Zhang YL (2011) The effect of dietary Panax ginseng polysaccharide extraction the immune responses in white shrimp, Litopenaeus vannamei. Fish Shellfish Immunol 30:495-500

Lv Y, Liu Z, Tian Y, Chen H (2013) Effect on morphology, oxidative stress and energy metabolism enzymes in the testes of mice after a 13-week oral administration of melamine and cyanuric acid combination. Regul Toxicol Pharmacol 65:183-188

Mahardika K, Mastuti I, Zafran Z (2017) Histopathological study on nephropathy caused by oral administration with melamine and cyanuric acid in humpback grouper (Cromileptes altivelis). Aquac Aquar Conserv Legisl Int J Bioflux Soc 10:328-334

Maule AG, Gannam AL, Davis JW (2007) Chemical contaminants in fish feeds used in federal salmonid hatcheries in the USA. Chemosphere 67:1308-1315

O'Keefe T, Campabadal CA (2015) Storage and handling of feeds for fish and shrimp. In: Davis DA (ed) Feed and feeding practices in aquaculture. Woodhead Publishing, Oxford

Pacini N, Prearo M, Abete MC, Brizio P, Dörr AJ, Reimschuessel R, Andersen W, Gasco L, Righetti M, Elia AC (2013) Antioxidant responses and renal crystal formation in rainbow trout treated with melamine administered individually or in combination with cyanuric acid. J Toxicol Environ Health Part A 76:491-508

Mycotoxin contamination of animal feed. In: Gremmels JF (ed) Animal feed contamination, Woodhead Publishing, Oxford

Phromkunthong W, Nuntapong N, Boonyaratpalin M, Kiron V (2013) Toxicity of melamine, an adulterant in fish feeds: experimental assessment of its effects on tilapia. J Fish Dis 36:555-568

Phromkunthong W, Choochuay P, Kiron V, Nuntapong N, Boonyaratpalin M (2015a) Pathophysiological changes associated with dietary melamine and cyanuric acid toxicity in red tilapia. J Fish Dis 38:161-173

Phromkunthong W, Nuntapong N, Wanlem S, Boonyaratpalin M (2015b) A study on growth, histopathology and oxidative stress in Asian sea bass on diets with various loadings of melamine and cyanuric acid adulterants. Aquaculture 435:336-346

Pirarat N, Katagiri T, Chansue N, Ponpornpisit A, Endo M, Maita M (2012) The pathological effects of melamine and cyanuric acid in the diet of walking catfish (Clarias batrachus). J Comp Pathol 147:259-266

Puschner B, Poppenga RH, Lowenstine LJ, Filigenzi MS, Pesavento PA (2007) Assessment of melamine and cyanuric acid toxicity in cats. J Vet Diagn Invest 19:616-624

Qiu M, Wang Y, Wang X, Sun L, Ye R, Xu D, Dai Z, Liu Y, Bi S, Yao Y, Gooneratne R (2016) Effects of T-2 toxin on growth, immune function and hepatopancreas microstructure of shrimp (Litopenaeus vannamei). Aquaculture 462:35-39

Reimschuessel R, Gieseker CM, Miller RA, Ward J, Boehmer J, Rummel N, Heller DN, Nochetto C, de Alwis GK, Bataller N, Andersen WC, Turnipseed SB, Karbiwnyk CM, Satzger RD, Crowe JB, Wilber NR, Reinhard MK, Roberts JF, Witkowski MR (2008) Evaluation of the renal effects of experimental feeding of melamine and cyanuric acid to fish and pigs. Am J Vet Res 69:1217-1228

Reimschuessel R, Evans ER, Stine CB, Hasbrouck N, Mayer TD, Nochetto C, Gieseker CM (2010) Renal crystal formation after combined or sequential oral administration of melamine and cyanuric acid. Food Chem Toxicol 48:2898-2906

Rick W, Stegbauer HP (1974) Alpha amylase measurement of reducing groups. In: Bergmeyer HV (ed) Methods of enzymatic analysis, Academic Press, New York

Roviello G, Ricciotti L, Ferone C, Ferone C, Colangelo F, Tarallo O (2015) Fire resistant melamine based organic-geopolymer hybrid composites. Cement Concr Compos 59:89-99 
Samranrat N, Muangyao P, Thongrod S, Paengmee R, Yaponha L (2011) Effect of melamine in feed on growth, survival rate, feed conversion ratio and pathological changes in black tiger shrimp (Peneaus monodon Fabricius, 1798). Technical Paper No. 8/2011. Coastal Aquatic Feed Research Institute, Department of Fisheries, Bangkok (article in Thai)

Seebaugh DR, L'Amoreaux WJ, Wallace WG (2011) Digestive toxicity in grass shrimp collected along an impact gradient. Aquat Toxicol 105:609-617

Senphan T, Benjakul S (2012) Compositions and yield of lipids extracted from hepatopancreas of Pacific white shrimp (Litopenaeus vannamei) as affected by prior autolysis. Food Chem 134:829-835

Shen WY, Fu LL, Li WF, Zhu YR (2010) Effect of dietary supplementation with Bacillus subtilis on the growth, performance, immune response and antioxidant activities of the shrimp (Litopenaeus vannamei). Aquac Res 41:1691-1698

Smoker M, Krynitsky AJ (2008) Interim method for determination of melamine and cyanuric acid residues in foods using LC-MS/ MS. Version 1.0. US FDA/CFSAN Laboratory Information Bulletin LIB No. 4422. US-FDA, Maryland

Song HL, Tan BP, Chi SY, Liu Y, Chowdhury MAK, Dong XH (2017) The effects of a dietary protease-complex on performance, digestive and immune enzyme activity, and disease resistance of Litopenaeus vannamei fed high plant protein diets. Aquac Res 48:2550-2560

Sritunyalucksana K, Söderhäll K (2000) The proPO and clotting system in crustaceans. Aquaculture 191:53-69

Stine CB, Reimschuessel R, Gieseker CM, Evans ER, Mayer TD, Hasbrouck NR, Tall E, Boehmer J, Gamboa da Costa G, Ward JL (2011) A no observable adverse effects level (NOAEL) for pigs fed melamine and cyanuric acid. Regul Toxicol Pharmacol 60:363-372

Stine CB, Nochetto CB, Evans ER, Gieseker CM, Mayer TD, Hasbrouck NR, Reimschuessel R (2012) Depletion of melamine and cyanuric acid in serum from catfish Ictalurus punctatus and rainbow trout Oncorhynchus mykiss. Food Chem Toxicol 50:3426-3432

Supamattaya K, Kiriratnikom S, Boonyaratpalin M, Borowitzka L (2005) Effect of a Dunaliella extract on growth performance, health condition, immune response and disease resistance in black tiger shrimp (Penaeus monodon). Aquaculture 248:207-216

Thai Agricultural Standards TAS 7401-2009 (2009) National Bureau of Agricultural Commodity and Food Standards, Ministry of Agriculture and Cooperatives. "Good Aquaculture Practices for Marine Shrimp Farm” in the Royal Gazette. vol. 126 (Section 187D, Dated 28 December B.E. 2552, 2009)

Trasviña-Arenas CH, Garcia-Triana A, Peregrino-Uriarte AB, Yepiz-Plascencia G (2013) White shrimp Litopenaeus vannamei catalase: Gene structure, expression and activity under hypoxia and reoxygenation. Comp Biochem Physiol Part B Biochem Mol Biol 164:44-52

US-FDA (U.S. Food and Drug Administration) (2007) Interim melamine and analogues safety/risk assessment peer review report. United States Food and Drug Administration, Washington, DC

Wanlem S, Supamattaya K, Tantikitti C, Prasertsan P, Graidist P (2011) Expression and applications of recombinant crustacean hyperglycemic hormone from eyestalks of white shrimp (Litopenaeus vannamei) against bacterial infection. Fish Shellfish Immunol 30:877-885

WHO (World Health Organization) (2009) Background paper on occurrence of melamine in foods and feed. WHO, Geneva

World Bank (2013) Fish to 2030: prospects for fisheries and aquaculture. Agriculture and Environmental Services Discussion Paper No. 3 World Bank Group, Washington DC

Xue J, Ai Q, Mai K, Xu W, Yang Y, Liufu Z (2011) Effects of melamine on growth performance and skin color of darkbarbel catfish (Pelteobagrus vachelli). Aquaculture 320:142-146

Yang JJ, Yang Z, Zhang T (2010) Action potential changes associated with impairment of functional properties of sodium channels in hippocampal neurons induced by melamine. Toxicol Lett 198:171-176

Yin RH, Li XT, Wang X, Li HS, Yin RL, Liu J, Dong Q, Wang WC, Yuan J, Liu BS, Han XH, He JB, Bai WL (2016) The effects of melamine on humoral immunity with or without cyanuric acid in mice. Res Vet Sci 105:65-73

You H, Zhu JF, She RP, Chang LL, Shi RH, Ding Y, Chi LJ, Liu B, Yue Z, Tian JJ, Mao JJ, Su LF (2012) Induction of apoptosis in the immature mouse testes by a mixture of melamine and cyanuric acid. J Integr Agric 11:2058-2066

Yu YY, Chen SJ, Chen M, Tian LX, Niu J, Liu YJ, Xu DH (2016) Effect of cadmium-polluted diet on growth, salinity stress, hepatotoxicity of juvenile Pacific white shrimp (Litopenaeus vannamei): protective effect of $\mathrm{Zn}$ (II)-curcumin. Ecotoxicol Environ Saf 125:176-183

Zenteno-Savín T, Saldierna R, Ahuejote-Sandoval M (2006) Superoxide radical production in response to environmental hypoxia in cultured shrimp. Comp Biochem Physiol C Toxicol Pharmacol 142:301-308

Zhao W, Wang L, Liu M, Jiang K, Wang M, Yang G, Qi C, Wang B (2017) Transcriptome, antioxidant enzyme activity and histopathology analysis of hepatopancreas from the white shrimp Litopenaeus vannamei fed with aflatoxin B1(AFB1). Dev Comp Immunol 74:69-81

Zokaeifar H, Balcázar JL, Saad CR, Kamarudin MS, Sijam K, Arshad A, Nejat N (2012) Effects of Bacillus subtilis on the growth performance, digestive enzymes, immune gene expression and disease resistance of white shrimp, Litopenaeus vannamei. Fish Shellfish Immunol 33:683-689

\section{Publisher's Note}

Springer Nature remains neutral with regard to jurisdictional claims in published maps and institutional affiliations. 